\title{
Effects of Habitat Structure and Fragmentation on Diversity and Abundance of Primates in Tropical Deciduous Forests in Bolivia
}

\author{
Lennart W. Pyritz • Anna B. S. Büntge • \\ Sebastian K. Herzog • Michael Kessler
}

Received: 26 March 2009 / Accepted: 22 March 2010 /

Published online: 7 August 2010

(C) The Author(s) 2010. This article is published with open access at Springerlink.com

\begin{abstract}
Habitat structure and anthropogenic disturbance are known to affect primate diversity and abundance. However, researchers have focused on lowland rain forests, whereas endangered deciduous forests have been neglected. We aimed to investigate the relationships between primate diversity and abundance and habitat parameters in 10 deciduous forest fragments southeast of Santa Cruz, Bolivia. We obtained primate data via line-transect surveys and visual and acoustic observations. In addition, we assessed the vegetation structure (canopy height, understory density), size, isolation time, and surrounding forest area of the fragments. We interpreted our results in the context of the historical distribution data for primates in the area before fragmentation and interviews with local people. We detected 5 of the 8 historically observed primate species: Alouatta caraya, Aotus azarae boliviensis, Callithrix melanura, Callicebus donacophilus, and Cebus libidinosus juruanus. Total species number and detection rates decreased with understory density. Detection rates also negatively correlated with forest areas in the surroundings of a fragment, which may be due to variables
\end{abstract}

L. W. Pyritz ( $\square)$

Behavioral Ecology \& Sociobiology Unit, German Primate Center, 37077 Göttingen, Germany e-mail: LennartPyritz@gmx.net

\section{A. B. S. Büntge}

Department of Evolutionary Genetics, Max-Planck-Institute for Evolutionary Biology, 24306 Plön, Germany

\section{S. K. Herzog}

Asociación Armonía - BirdLife International, Casilla 3566, Santa Cruz de la Sierra, Bolivia

M. Kessler

Institute of Systematic Botany, University of Zurich, 8008 Zurich, Switzerland 
not assessed, i.e., fragment shape, distance to nearest town. Observations for Alouatta and Aotus were too few to conduct further statistics. Cebus and Callicebus were present in $90 \%$ and $70 \%$ of the sites, respectively, and their density did not correlate with any of the habitat variables assessed, signaling high ecological plasticity and adaptability to anthropogenic impact in these species. Detections of Callithrix were higher in areas with low forest strata. Our study provides baseline data for future fragmentation studies in Neotropical dry deciduous forests and sets a base for specific conservation measures.

Keywords Bolivia · Fragmentation · Habitat structure $\cdot$ Primates $\cdot$ Tropical deciduous forests

\section{Introduction}

Two main effects determine primate diversity and abundance in a forest site: 1) structural variables of the habitat or habitat quality and 2) indirect and direct anthropogenic impacts (Brown et al. 1985; Chapman and Peres 2001; Rylands 1987). At a regional scale, the diversity and density of primates in natural forests, both in the Neotropics and elsewhere, are known to depend on primary forest productivity, precipitation, and climatic seasonality (Peres 1997; Pinto et al. 2009). More locally, different monkey species typically occupy different forest microhabitats, preferring different forest strata or forest types of different structure, e.g., liana thickets (Bobadilla and Ferrari 2000; Mittermeier and van Roosmalen 1981; Wallace et al. 1998).

In terms of anthropogenic impacts, habitat fragmentation and directly related problems such as timber extraction and hunting for food, pets, and artifacts are the main threats for primates (Chapman et al. 2003; Laurance et al. 2000; Mittermeier et al. 2005; Robinson and Redford 1991). This may lead to directional shifts in community composition, crowding tendencies, and altered sex ratios (Baranga 2004; Chiarello and De Melo 2001; Martins 2005; Peres 2001; Rode et al. 2006). Generally speaking, primate richness decreased with fragment size (Harcourt and Doherty 2005), but in some isolated relatively small forest patches $\left(<50 \mathrm{~km}^{2}\right)$ primate densities have been found to increase, possibly owing to the absence of main predators such as large cats and birds of prey (González-Solís et al. 2001), the density compensation phenomenon (Peres and Dolman 2000), and the ecological plasticity of some primate species (González-Solís et al. 2001). Understanding the habitat preferences of a species is essential to predict its reaction to habitat disturbance and to put conservation measures in place. However, it is often difficult to disentangle the 2 effects regarding the distribution pattern of a species owing to naturally occurring hot- and coldspots for single species on a small scale (Brown et al. 1985), a lack of prefragmentation data from the same site (Chapman and Peres 2001), or synergistic interactions between environmental and anthropogenic factors (Pinto et al. 2009).

The aforementioned trends are mostly based on studies conducted in evergreen rainforests (Albernaz and Magnusson 1999; Mittermeier and van Roosmalen 1981; Rylands 1987). The Brazilian Atlantic forest and the Amazon Basin have 
been particular foci of research (Chiarello 2003; Laurance and Bierregaard 1997; Phillips et al. 2004; Schwarzkopf and Rylands 1989). However, $40-50 \%$ of all tropical forests was originally deciduous forest (Gentry 1995; Janzen 1988; Murphy and Lugo 1995), which are also home to a large number of often endangered and little known primate species (Mittermeier et al. 2005; Nowak 1999). Further, this forest type is among the most endangered lowland tropical forest ecosystems (Janzen 1988) owing to a relatively high soil fertility when compared to other tropical biomes and, consequently, a high human colonization with intensive agricultural activity (Steininger et al. 2001; Williams 1989). Today, only few large areas of intact deciduous tropical forest remain in the tropics and subtropics (Maas 1995), and a number of researchers have pointed out a serious neglect of studies and conservation programs in these ecosystems (SánchezAzofeifa et al. 2005; Wallace et al. 1998).

To begin to remedy these deficiencies, we collected data on primate diversity and abundance in the Chiquitano dry forest ecoregion in lowland Bolivia. This ecoregion has a size of $c a .102,000 \mathrm{~km}^{2}$ (Ibisch et al. 2003) and contains the largest until recently unfragmented area of deciduous tropical forest in the world (Gentry 1993). However, over the last decades, the area has undergone profound changes through deforestation and fragmentation (Camacho et al. 2001; Steininger et al. 2001). Our aim was to identify natural (vegetation structure) and anthropogenic (fragmentation, isolation) factors influencing primate diversity and abundance in the endangered deciduous forests. To tease apart the effects of habitat structure and anthropogenic disturbance despite the restrictions of our small scale, short-term (December 2005March 2006) study, we sampled fragments that differed systematically in their natural vegetation parameters and human impact factors and controlled for correlations between the habitat variables. In addition, we collected data on primate distribution and abundance before fragmentation from the literature and interviews with local landowners. We discuss our findings with regard to taxon-specific habitat preferences and aim to identify species that are immediately endangered by fragmentation in the study area.

\section{Materials and Methods}

\section{Study Area}

We collected data in 10 forest fragments $\leq 30 \mathrm{~km}$ south and east of the Bolivian city of Santa Cruz de la Sierra $\left(17^{\circ} 44^{\prime}-17^{\circ} 55^{\prime} \mathrm{S}\right.$; $62^{\circ} 53^{\prime}-63^{\circ} 10^{\prime} \mathrm{W}$; Fig. 1). We chose 19 fragments according to their size and accessibility after overflying the area in a Cessna airplane. Subsequently, we visited the fragments and visually assessed their average tree height and shrub density as well as the percentage of forested area in the surroundings of the remnants. We then chose 2 or 3 fragments of approximately the same size in 4 different size ranges (1-3 ha, 3-5 ha, 10$70 \mathrm{ha}$, and $>150 \mathrm{ha}$ ) that differed in vegetation structure and surrounding landscape matrix.

Forest fragments ranged in size from 1.1 to 303 ha (Table I). Most were situated on private farmland (LC1, LC2, IG, PA1, PA2, SR, and ER). Three other study sites 


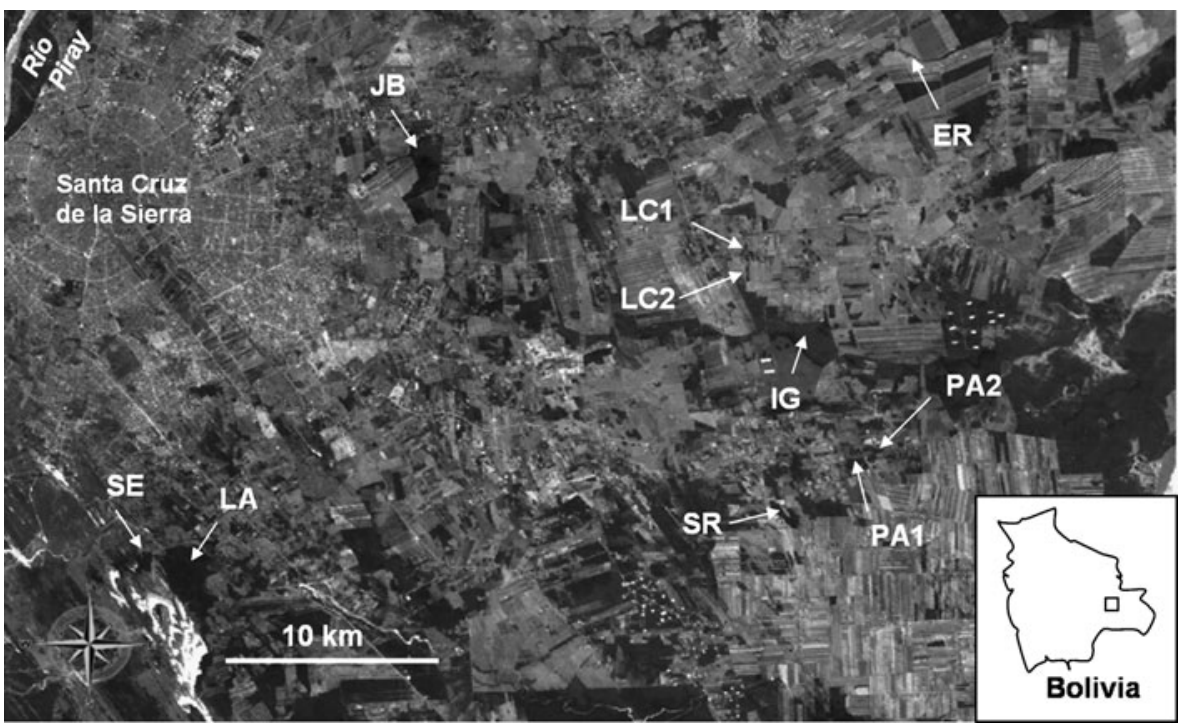

Fig. 1 Detail of the study area east of Santa Cruz de la Sierra in the Departamento de Santa Cruz, Bolivia, with locations of the study sites. Black and dark gray areas in the satellite image indicate forest areas. Study site abbrevations: ER = El Rodeo, IG = Ignacio, JB = Jardín Botánico, LC1 = Los Cupesis 1, LC2 = Los Cupesis 2, LA = Lomas de Arena, P1 = Paurito 1, P2 = Paurito 2, SE = Sendéro Ecológico, $\mathrm{SR}=$ Santa Rita. (Satellite image modified from NASA World Wind 1.3.5.).

included the Botanical Garden (JB) of Santa Cruz and 2 forest fragments in the small reserve Parque Regional Lomas de Arena $20 \mathrm{~km}$ south of the city center (SE, LA). We used an annotated species list for the local primate fauna of Lomas de Arena (LA) from previous surveys by Guillén Villarroel et al. (2004).

All forest fragments had similar topographic, edaphic, and climatic conditions, as well as the same altitude of $c a .430 \mathrm{~m}$. The entire study area lies in the alluvial plain of the Río Grande, characterized by a flat topography and Andean-derived alluvial sediments deposited by the river (Krüger 2006; Steininger et al. 2001). The climate is tropical and seasonally wet, with a mean temperature of $27^{\circ} \mathrm{C}$ and a mean annual precipitation of $1,500 \mathrm{~mm}$ with a standard deviation of $283 \mathrm{~mm}$ (Krüger 2006). About $70 \%$ of the annual precipitation falls in the rainy season from October to March (Krüger 2006). The study area is situated in a biogeographic transition zone between the mesophytic, semideciduous Cerrado forests of the Chiquitano dry forest ecoregion and the meso- to xerophytic and lower-stature woodlands of the Gran Chaco (Ibisch et al. 2003). The typical Cerrado forest, which was present in most of the study sites, shows 2 tree strata, sporadically overtopped by emergents like Schinopsis brasiliensis. The superior stratum consists of a 15-30 m tall, partially closed canopy with (semi-)deciduous tree species like Anadenanthera colubrina, Acosmium cardenasii, Caesalpinia floribunda, Aspidosperma cylindrocarpon, Chorisia speciosa, and Tabebuia impetiginosa. The lower stratum (3-15 m tall) consists mostly of evergreen trees, shrubs, and liana (Killeen et al. 1998; Navarro and Maldonado 2002). Further east and south of Santa Cruz de la Sierra, the xerophytic woodlands of the Chaco begin. These semideciduous forests are low (4$10 \mathrm{~m}$, emergents $\leq 20 \mathrm{~m}$ tall) with open canopies, and partially feature a thick, $\leq 6 \mathrm{~m}$ 


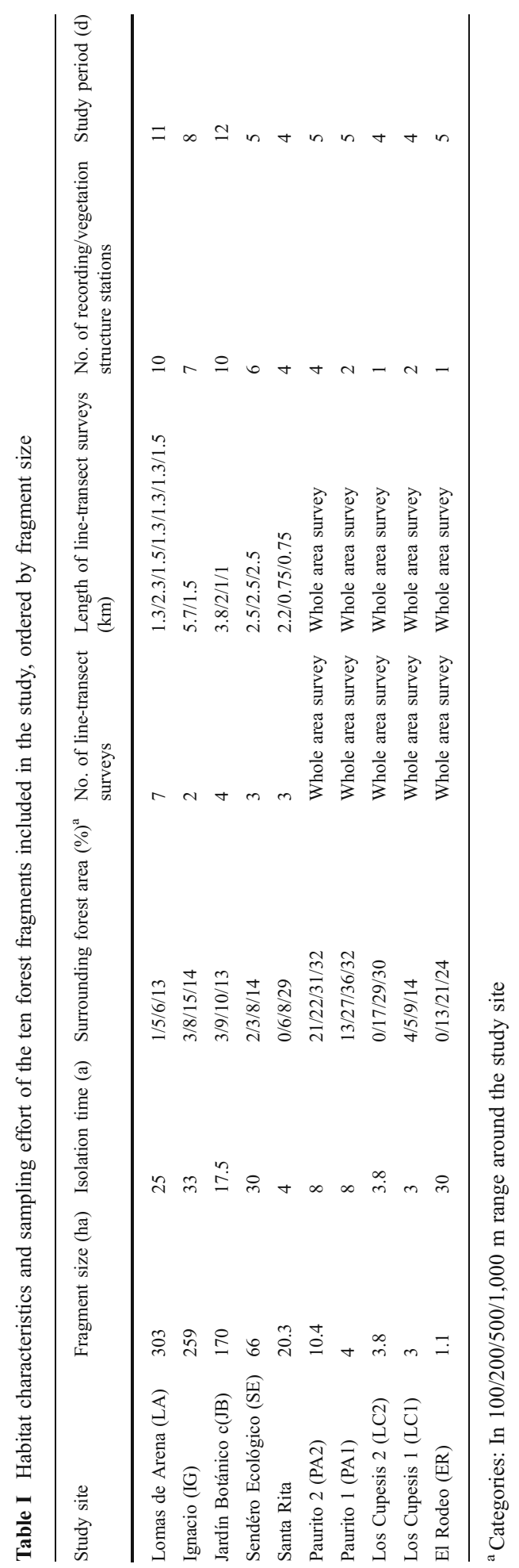


tall thorn scrub. Dominant tree species include Aspidosperma quebracho-blanco, Schinopsis cornuta, Schinopsis lorentzii, and the tree-cactus species Browningia caineana (Navarro and Maldonado 2002). The landscape matrix in which the study sites are immersed is composed predominantly of pasturelands and agricultural fields, interspersed by other small forest fragments.

\section{Data Collection}

We collected data from December 2005 to March 2006 during the austral summer, which is characterized by frequent rainfalls $(180 \mathrm{~mm} / \mathrm{mo})$ and constantly high temperatures of $30^{\circ} \mathrm{C}$ on average (Navarro and Maldonado 2002). We restricted data collection to these months to guarantee similar climate and vegetation conditions over the entire study period and avoid seasonal bias in the probability of detecting species. Time of data acquisition per site was 4-12 days, depending on fragment size (Table I). We interrupted data collection during heavy rainfalls. However, rainfalls were usually short, so we continued data collection after $30 \mathrm{~min}$ or so. For each forest fragment we determined its size, isolation time, percentage of forest cover in the surrounding matrix area, and data on vegetation structure (Table I). We determined fragment size using a handheld Garmin E-Trex GPS navigation device, and, for the two largest study sites (LA and IG), by measuring size on a satellite image from NASA World Wind 1.3.5 after enlarging the image via Photoshop 7.0 (Adobe Systems Inc. 2002; resolution: $40 \times 40$ m, Fig. 1). We obtained data on isolation time of the forest fragments through interviews with landowners when we requested permission to work on their property. For the analysis of the surrounding forest area we assessed the percentage of forested area in different ranges around the study sites. We drew a line tracing the fragment shape at $100 \mathrm{~m}, 200 \mathrm{~m}, 500 \mathrm{~m}$, and $1,000 \mathrm{~m}$ of the fragment border on the enlarged NASA satellite image in Photoshop using the measure tool. Then we counted all pixels in the space between the fragment border and the drawn line. We identified picture elements representing forest area by their dark green color and matched borders of the fragments and surrounding forest blocks in the satellite image with GPS coordinates taken in the field.

We obtained data on vegetation structure at a number of points varying according to fragment size (Table I), each covering a $7.5 \mathrm{~m}$ radius circle. Data included mean canopy height, number of lying and standing dead logs with a diameter at breast height $(\mathrm{DBH})>16 \mathrm{~cm}$, number of shrubs (woody plants $0.5-3 \mathrm{~m}$ tall), and number of trees (woody plants $>3 \mathrm{~m}$ tall) in 4 DBH classes: $<16 \mathrm{~cm}, 16-30 \mathrm{~cm}, 31-60 \mathrm{~cm}$, $>60 \mathrm{~cm}$. For each vegetation structure variable we calculated the mean for each fragment. We also calculated the mean basal wood area $\left(\mathrm{m}^{2} / \mathrm{ha}\right)$ for each study site using the total number of trees. Because we did not measure the DBH values of trees in the smallest class $(<16 \mathrm{~cm})$ individually, we assumed a mean DBH of $11 \mathrm{~cm}$ for each tree for the calculations.

Before fieldwork, we took references for the primate species reported for the study area and their distributional ranges from Anderson (1997), Emmons and Feer (1997), Eisenberg and Redford (1999), Salazar-Bravo et al. (2003), and Guillén Villarroel et al. (2004) and asked local landowners which species they have seen in the study site in the past. The taxonomy we use follows Groves (2001), except for Callicebus donacophilus, which van Roosmalen et al. (2002) 
considered as a full species. We acquired primatological data (number of species, detections of different individuals/groups per study day) in the field by standardized, opportunistic visual surveys using a pair of Zeiss $10 \times 40$ binoculars and guide books (Eisenberg and Redford 1999; Emmons and Feer 1997; Appendix 1). In addition, we collected acoustic data using standardized point count sound recordings at the vegetation structure stations via a Sony TCM 5000EV portable cassette recorder and a Sennheiser ME 80 directional microphone (Table I). We set acoustic data collection points $250 \mathrm{~m}$ apart. Thereby, we were able to separate clearly primate vocalizations between 2 neighboring points in the recordings and avoid multiple counts of the same individuals. We conducted the recordings following Haselmayer and Quinn (2000). Recording time was $\geq 8 \mathrm{~min}$ per point. During the recordings, we stood silently on the point of data collection and changed the orientation of the microphone every minute for the first $8 \mathrm{~min}$ of the recording time in a fixed manner (east, south, west, north, repeated once). If primates vocalized, we directed the microphone freely in the direction of the vocalizations for another $7 \mathrm{~min}$ to collect additional recordings to facilitate identification of species. We sampled $\geq 3$ recordings per sound recording station, regardless of primate vocalizations heard. Each morning, we conducted $\leq 6$ recordings beginning between 05:00 and 06:00 h for $c a .3 \mathrm{~h}$, depending on weather conditions. We changed the order in which recording stations were visited in a given fragment daily. In total, we obtained 244 point count recordings. In addition, we conducted 1 or 2 short recordings $(5-10 \mathrm{~min}$ ) in each fragment after sunset (19:50-20:50 h) to detect crepuscular and nocturnal species like Aotus azarae boliviensis. We identified primate vocalizations heard or recorded using Emmons et al. (1997). We considered vocalizations recorded from different directions as independent. Because it was not possible to assess the exact number of callers in most recordings, we rated each vocalization as detection of 1 individual in the further analyses. In forest fragments $<20$ ha, we surveyed the whole area (Schwarzkopf and Rylands 1989); in larger fragments we performed standardized line-transect surveys (Buckland et al. 1993; Peres 1999; Table I) to assess primate diversity and detection rates.

\section{Data Analyses}

To reduce the number of habitat parameters, we performed principal component analyses (PCA), followed by bivariate correlation analyses (Pearson correlation, 2tailed test of significance) to test for mutual dependence between the habitat parameters. We tested the impact of the PCs on primate diversity and abundance using multiple regression analyses. Variables tested were total species number and mean number of primate detections per study day (in total and by species; visual and acoustic detections combined). We took mean numbers of detections per study day as a proxy for population densities in this study, because we were not able to perform a large number of standardized line-transects in every study site due to constraints caused by a parallel ornithological data collection. Nevertheless, we consider our results as robust because we were able to assess the entire primate community in small fragments $<20$ ha, and, therefore, could avoid double counting of the same individuals. In larger fragments, the combination of different methods 
(acoustic recordings, transect walks and opportunistic observations by 3 researchers) should have provided a realistic image of the different species and groups living in the particular fragment. To avoid multiple counts of the same individuals, we compared observations of the same species from different researchers regarding time and locality each day. We counted observations separately only if they were made at approximately the same time but $\geq 250 \mathrm{~m}$ apart from each other. Significance level is $p \leq 0.05$.

\section{Results}

\section{Habitat Parameters}

Fragment size and isolation time correlated poorly with all other habitat variables, so we excluded them from the PCA data set and used them as single variables in further analyses. PCA of the 11 remaining variables revealed 3 components with eigenvalues $>1$, cumulatively accounting for $82.3 \%$ of the total variance (Table II). The first component showed heavy factor loadings for all variables concerning the percentage of forest area in different sized ranges around the fragments, so we labeled it "surrounding forest area." The second component showed heavy factor loadings for canopy height, number of trees of the largest category, basal tree area, and number of dead logs, and was labeled "forest maturity." We labeled the third component "understory density" due to heavy

Table II Eigenvalues and proportions of variance of the 3 components extracted in the principal component analysis (PCA) and rotated component matrix

\begin{tabular}{lllll}
\hline & & \multicolumn{2}{l}{ Component } & \\
\cline { 3 - 5 } & & $\begin{array}{l}\text { Surrounding forest } \\
\text { area }\end{array}$ & $\begin{array}{l}\text { Forest } \\
\text { maturity }\end{array}$ & $\begin{array}{l}\text { Understory } \\
\text { density }\end{array}$ \\
\hline Total & & 4.168 & 3.159 & 1.732 \\
Initial eigenvalues & \% of variance & 37.889 & 28.714 & 15.745 \\
& Cumulative \% & 37.889 & 66.603 & 82.348 \\
Variables & Canopy height & -0.027 & $\mathbf{0 . 8 2 2}$ & -0.200 \\
& Number of shrubs & 0.150 & 0.034 & $\mathbf{0 . 9 5 9}$ \\
& Small trees & 0.048 & -0.445 & $\mathbf{0 . 8 4 0}$ \\
& Middle-sized trees & -0.359 & -0.206 & $\mathbf{0 . 8 1 4}$ \\
& Large trees & 0.033 & $\mathbf{0 . 8 7 7}$ & -0.343 \\
& Basal wood area & 0.483 & $\mathbf{0 . 6 7 4}$ & -0.237 \\
& Dead wood & -0.064 & $\mathbf{0 . 8 3 5}$ & 0.104 \\
& \% forest in $100 \mathrm{~m}$ radius & $\mathbf{0 . 7 2 5}$ & -0.242 & -0.158 \\
& \% forest in $200 \mathrm{~m}$ radius & $\mathbf{0 . 9 7 4}$ & -0.010 & -0.033 \\
& \% forest in $500 \mathrm{~m}$ radius & $\mathbf{0 . 9 5 6}$ & 0.123 & -0.050 \\
& \% forest in 1000 m radius & $\mathbf{0 . 8 8 9}$ & 0.172 & 0.074 \\
\hline
\end{tabular}

Heavy loadings for each component are displayed in bold 
factor loadings for the number of shrubs and the number of small and mid-sized trees (16-60 cm DBH).

\section{Primate Data}

We detected the presence of Alouatta caraya, Aotus azarae boliviensis, Callithrix melanura, Callicebus donacophilus, and Cebus libidinosus juruanus. Species observed in the greatest number of sites were Cebus libidinosus juruanus (9 sites), Callicebus donacophilus (7 sites), and Callithrix melanura (6 sites). We detected Aotus azarae boliviensis and Alouatta caraya in only 2 and 1 forest fragment, respectively (Appendix 1). We had only acoustic evidence for howlers in the JB. However, recent visual observations confirmed that the species is Alouatta caraya (pers. comm. by Rebecca Rimbach to Lennart Pyritz, January 2010), an unmistakable species due to sexual dichromatism. Total species number and mean primate detections per day decreased significantly with understory density; surrounding forest area also had a significant negative impact on mean primate detections per day. Fragment size did not have a significant impact on mean primate detections per day (Table III).

We conducted single-species analyses only for Callithrix melanura, Cebus libidinosus juruanus, and Callicebus donacophilus, because observation numbers were too low for Alouatta caraya and Aotus boliviensis. Multiple regression models were significant for Callithrix melanura and Callicebus donacophilus (Table IV), but not for Cebus libidinosus juruanus. Forest maturity, understory density, and surrounding forest area correlated negatively with mean detections of Callithrix melanura per day. For Callicebus donacophilus, the regression model was significant, but no single predictor variable had any significant impact on mean daily detections.

\section{Discussion}

Of the 8 primate species that have been reported historically in the vicinity of Santa Cruz (Anderson 1997), we observed only 5 in the present study. This could be due to

Table III Multiple regression models including habitat parameters, total primate species number, and mean number of detections per day

\begin{tabular}{|c|c|c|c|c|c|}
\hline Dependent variable & $\begin{array}{l}\text { Adjusted } \\
R^{2}\end{array}$ & $\begin{array}{l}p \text {-value for } \\
\text { model }\end{array}$ & $\begin{array}{l}\text { Predictor } \\
\text { variables }\end{array}$ & $\begin{array}{l}\text { Standardized beta } \\
\text { coefficients }\end{array}$ & $\begin{array}{l}p \text {-values for single } \\
\text { predictor variables }\end{array}$ \\
\hline \multirow[t]{2}{*}{ Total species no. } & \multirow[t]{2}{*}{0.79} & \multirow[t]{2}{*}{$0.00 *$} & $\begin{array}{l}\text { Understory } \\
\text { density }\end{array}$ & -0.84 & $0.00 *$ \\
\hline & & & Fragment size & 0.23 & 0.19 \\
\hline \multirow[t]{2}{*}{$\begin{array}{l}\text { Mean no. of } \\
\text { detections per day }\end{array}$} & \multirow[t]{2}{*}{0.81} & \multirow[t]{2}{*}{$0.01 *$} & $\begin{array}{l}\text { Understory } \\
\text { density }\end{array}$ & -0.80 & $0.00 *$ \\
\hline & & & $\begin{array}{l}\text { Surrounding } \\
\text { forest area }\end{array}$ & -0.47 & $0.02 *$ \\
\hline
\end{tabular}

Significance is indicated by a * 
Table IV Multiple regression models including habitat parameters and mean number of detections per day for Callithrix melanura and Callicebus donacophilus, respectively

\begin{tabular}{|c|c|c|c|c|c|}
\hline $\begin{array}{l}\text { Dependent } \\
\text { variable }\end{array}$ & $\begin{array}{l}\text { Adjusted } \\
R^{2}\end{array}$ & $\begin{array}{l}p \text {-value } \\
\text { for model }\end{array}$ & $\begin{array}{l}\text { Predictor } \\
\text { variables }\end{array}$ & $\begin{array}{l}\text { Standardized beta } \\
\text { coefficients }\end{array}$ & $\begin{array}{l}p \text {-values for single } \\
\text { predictor variables }\end{array}$ \\
\hline \multirow{5}{*}{$\begin{array}{l}\text { Mean no. of } \\
\text { detections of } \\
\text { Callithrix melanura } \\
\text { per day }\end{array}$} & \multirow[t]{5}{*}{0.82} & \multirow[t]{5}{*}{$0.03 *$} & Forest maturity & -0.87 & $0.01 *$ \\
\hline & & & Understory density & -0.64 & $0.02 *$ \\
\hline & & & Surrounding forest area & -0.57 & $0.05^{*}$ \\
\hline & & & Fragment size & -0.53 & 0.06 \\
\hline & & & Isolation time & -0.33 & 0.27 \\
\hline \multirow{4}{*}{$\begin{array}{l}\text { Mean no. of } \\
\text { detections of } \\
\text { Callicebus } \\
\text { donacophilus per day }\end{array}$} & \multirow[t]{4}{*}{0.56} & \multirow[t]{4}{*}{$0.05 *$} & Isolation time & 0.64 & 0.11 \\
\hline & & & Understory density & -0.61 & 0.07 \\
\hline & & & Fragment size & 0.33 & 0.31 \\
\hline & & & Forest maturity & 0.30 & 0.29 \\
\hline
\end{tabular}

Significance is indicated by a *

sampling restraints; however, primate species' numbers observed in the present study match numbers reported in interviews with local people and from other recent surveys conducted in the same area and thus seem reliable. In JB, where 4 primate species were reported (pers. comm. by the director of JB Dario Melgar to Lennart Pyritz) we recorded a total of 5 species including Alouatta caraya that had not been mentioned by Melgar. In LA, we observed 3 species during the study period, only 1 (Aotus azarae boliviensis) less than in a reference mammal species list for the reserve (Guillén Villarroel et al. 2004).

Anderson (1997) reported sightings for Alouatta sara and Ateles chamek in our study area, 2 species we did not find. However, historical evidence is extremely sparse. Ateles chamek, e.g., is known only from 2 sightings in 1941 and 1976 . The 2 species are among the largest Neotropical primate species and have likely become locally extinct during the last decades owing to heavy hunting pressure (Peres 2001). Correspondingly, we recorded the largest species, Alouatta caraya, only in the botanical garden of Santa Cruz, which has been protected for $c a$. $20 \mathrm{yr}$. We did not observe the third historically sighted species-Saimiri boliviensis boliviensiswhich is usually rated a robust species present in forest fragments as small as $0.8-$ 2 ha (Baldwin and Baldwin 1976; Mittermeier and Coimbra-Filho 1977), and there are 13 sightings documented (Anderson 1997). However, none of the local people we interviewed, not even old Mennonite farmers who were among the first settlers in the area (Steininger et al. 2001), could ever remember having seen Saimiri boliviensis boliviensis. It may be that a large proportion was captured and kept as pets or sold long ago, as Saimiri seems to be of high value in the black market for exotic pets (Duarte-Quiroga and Estrada 2003). The rest may have disappeared as a result of genetic depletion, stochastic events, or social dysfunction (Lande and Barrowclough 1987). Otherwise, historical sightings reflect well the overall patterns of our observations (23 for Cebus libidinosus juruanus, 14 for Callicebus donacophilus, 8 for Aotus azarae boliviensis). However, Anderson (1997) quotes only 3 sightings for Callithrix melanura, a species we observed in more than half of our study sites. In general, historical observations from the area should be interpreted cautiously owing to often imprecise information. 
In contrast to the findings of many other studies (Chiarello and De Melo 2001; Martins 2005), the impact of fragment size on total species number was not significant (Table III). Further, none of the habitat variables correlated significantly with presence or detection rates of Cebus libidinosus juruanus and Callicebus donacophilus (Table IV). This might be explained by a general high ecological plasticity and adaptability of the local species (González-Solís et al. 2001), which has also been reported for Brazilian Atlantic forest primates (Chiarello 1999). In fact, a number of species/genera present in our study sites have been rated as highly robust to different habitat structures (Cebus apella: Wallace et al. 1998; Cebus libidinosus juruanus: Chiarello 2003; Callithrix melanura: Ferrari et al. 2003).

The high adaptability of capuchins (Cebus ssp.) is due to several factors. They are flexible in their diet (Galetti and Pedroni 1994), occupy a variety of different habitats including small remnants (Chiarello 2003), and recolonize fragments even if the surrounding second growth is only $2 \mathrm{~m}$ in height (Mittermeier and CoimbraFilho 1977). They even adapt to urban habitats (Fragaszy et al. 2004) and the vicinity of industrialized cities (Pinto et al. 2009). Titi monkeys (Callicebus ssp.) also seem to adapt to a small home range size. We observed Callicebus donacophilus in 7 out of 10 fragments, with some of them even displaying considerable proportions of low Chaco-forest (IG, LC1), and in remnants as small as 3 ha (LC1). Similar results on home range size were revealed by Mason (1971) for Callicebus, Kinzey et al. (1977) for Callicebus torquatis torquatus, and Chiarello (2003) for Callicebus personatus. A high tolerance toward habitat fragmentation and a high ecological adaptability were also reported for Callicebus coimbrai in the Atlantic forest, where a number of groups lived in fragments of only 3-20 ha in size (Jerusalinsky et al. 2006).

In general, except for SE and LA, where we observed a puma (Puma concolor) once and found puma footprints, respectively, we did not record any evidence, e.g., dung, vocalizations, of large predators in the study area. This also might facilitate primate persistence in small fragments (González-Solís et al. 2001).

Understory density showed a strong negative impact on total species number and primate detections per day (Table III) and detection rates of Callithrix melanura (Table IV). Probably, naturally occuring thick thorn scrub (Chaco forest type; Navarro and Maldonado 2002) that was present in some fragments south of the city center, e.g., IG, SR, was responsible for high scores in understory density. This thorn scrub is virtually impermeable and presumably too low $(3-4 \mathrm{~m})$ to provide an appropriate habitat for any Neotropical primate species (Coimbra-Filho and Mittermeier 1981). This probably accounts also for the absence of Callithrix melanura, although it often occurs in disturbed, human-made habitats (Albernaz and Magnusson 1999; Ferrari et al. 2003; Sussman 2000). Reduced visibility of species in fragments with high understory density may also play a role. However, we used different survey methods including acoustic recordings, which should have compensated for potential visual restraints.

Although Callithrix melanura has been observed in intermediate and high canopy forest (Stallings and Mittermeier 1989), forest maturity had a negative impact on the species, too (Table IV). This is in accordance with Hershkovitz (1977) and Wallace et al. (1998), who found that Callithrix generally prefers lower forest strata. Sites with intermediate scores in forest maturity may thus represent adequate habitat for 
the species providing lower forest strata, but no impermeable thorn scrub. In general, observed patterns could also be caused by the patchy distribution of Callithrix melanura even under undisturbed conditions in continuous forest, resulting in inhomogeneous patterns already before fragmentation (Ferrari et al. 2003; Veracini 1997).

The PCA component surrounding forest area (percentage of forest area in different sized ranges around the fragments) had a negative effect on primate detections per day (Table III) and numbers of Callithrix melanura (Table IV), which is surprising. Parameters not controlled for in this study, such as irregularities in fragment shape or the distance to the nearest farm/village, may account for this pattern (Arroyo-Rodríguez et al. 2008). In general, the number of variables tested in this study was restricted owing to time restraints, and the observed patterns may be caused by parameters that we did not evaluate. Pinto et al. (2009), e.g., stressed the importance of incorporating the landscape matrix, e.g., crops, gardens, swamp, fields, surrounding the fragments, because they found densities of Callicebus to correlate positively with agriculture, while the picture was reversed for Alouatta. Future studies in the area should therefore incorporate details on land use. Finally, some of our sites may represent natural "coldspots" of primate diversity irrespective of habitat quality (Pinto et al. 2009), which could have outweighed the effects of variables assessed in this study.

\section{Conclusions}

This was a short-term study, and future studies should also incorporate data on fragment shape; land use; distance to nearest town; and social parameters, e.g., income of the local people to estimate hunting pressure, in the study area, as these might explain distribution patterns better for single species than the variables we assessed. Nevertheless, our study provides a valuable basis for future studies of fragmentation in the threatened Neotropical dry forests. If the fragments studied by us are surveyed throughout the next years or decades, long-term effects, e.g., timedelayed extinctions, of species might be monitored and the impacts of habitat parameters and anthropogenic disturbance could be untangled more clearly, enabling specific conservation measures for endangered species.

Acknowledgments We thank the staff of Asociación Armonía/BirdLife International, Santa Cruz de la Sierra, and the Bolivian field assistants Monica San Cristobál and Dennis Soux for their support during field work. Permission to carry out field work and help with logistics was kindly provided by Dario Melgar and the staff of the Jardín Botánico of Santa Cruz, Herlan L. Paz Roca, and the guards of the Parque Regional Lomas de Arena, family Vargas-Salazar in Lomas de Arena, Stephan Henz, his family and employees, Líder Castedo, David Marpartida and his family, Señor Lino and his family, Ignacio Claure Blanco and the employees of his farm, and Roger Miserendino and the employees of the Agropecuaria El Rodeo. For financial support we are deeply thankful to the German Academic Exchange Service (DAAD) and to Christoph Hinkelmann and the Society for Tropical Ornithology (GTO). We also thank Jens-Peter Krüger from the Department of Landscape Conservation, Geographic Institute, University of Göttingen, who provided satellite images and maps of the study area. Eckhard Heymann and Rebecca Rimbach from the German Primate Center in Göttingen, Joanna Setchell, and 2 anonymous reviewers provided valuable comments on the manuscript. 


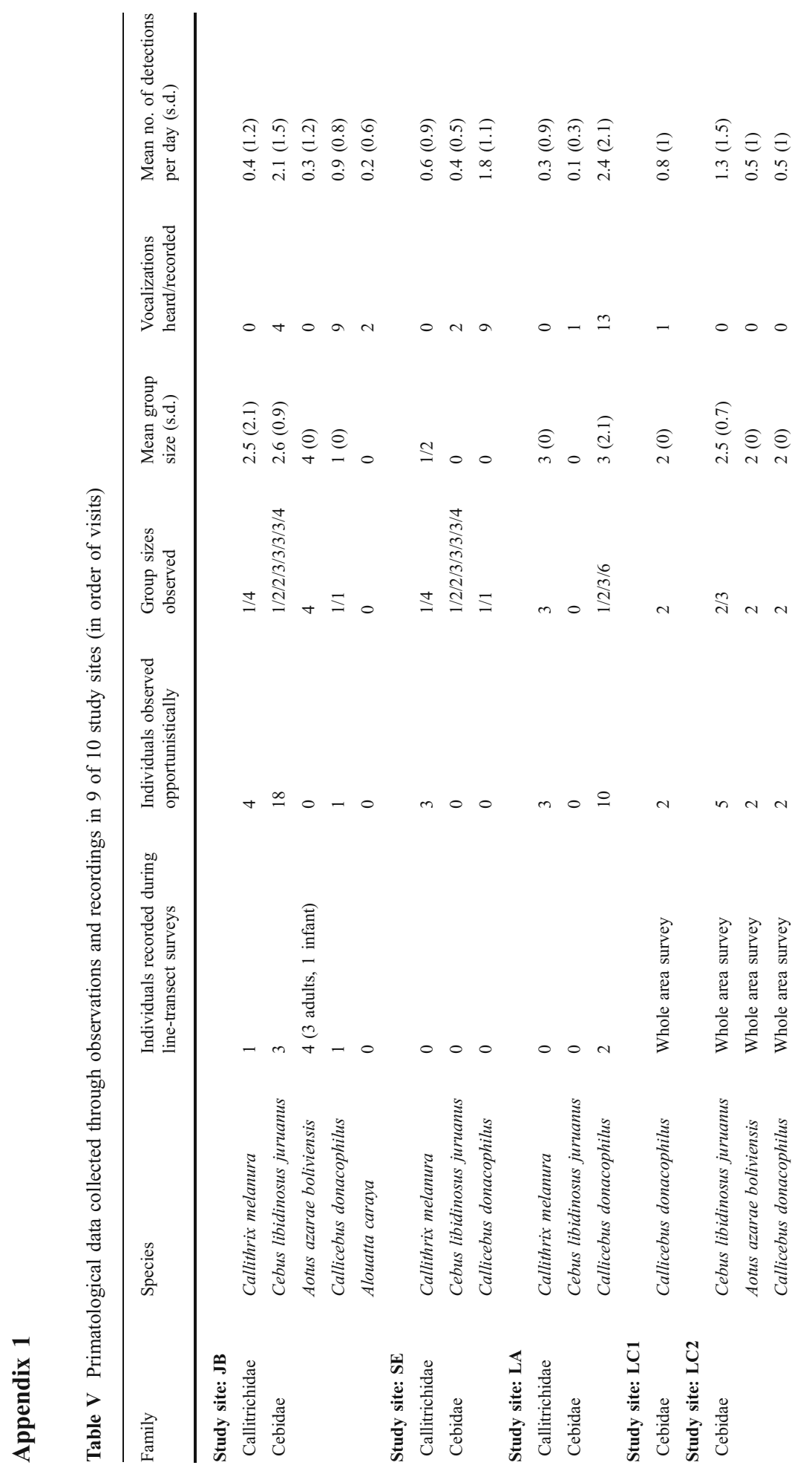




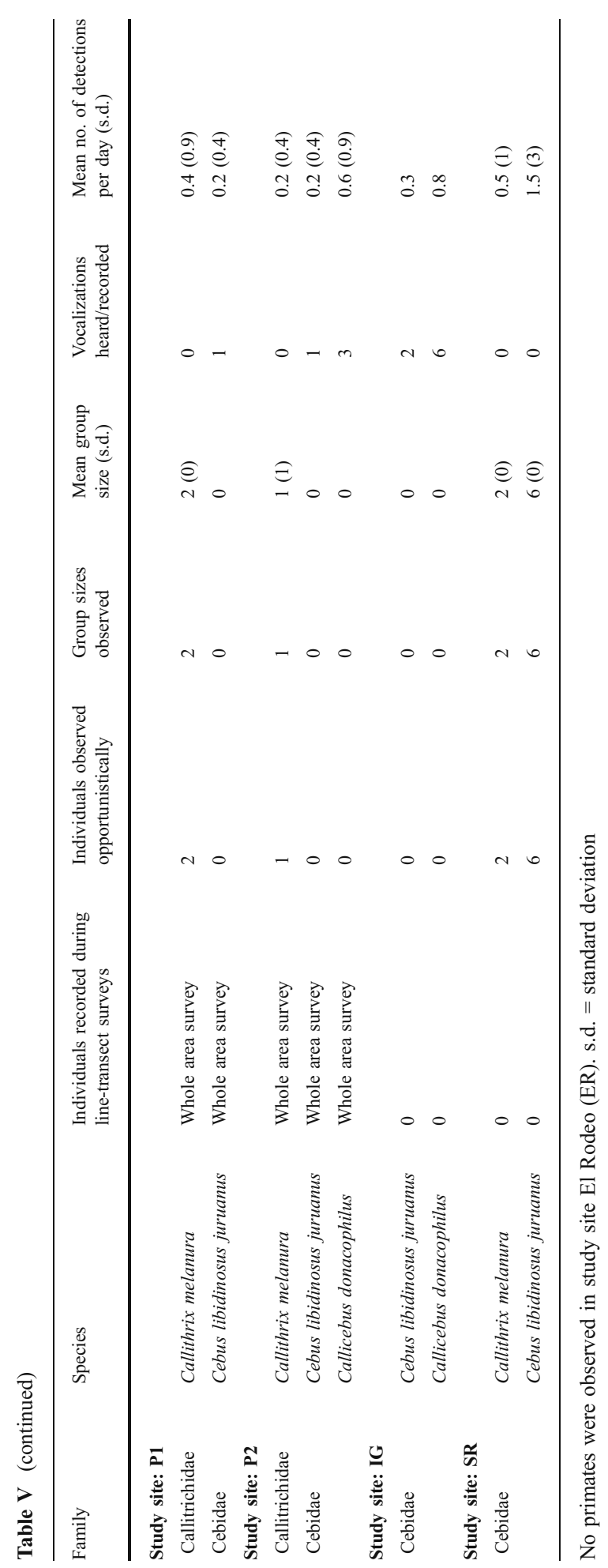


Open Access This article is distributed under the terms of the Creative Commons Attribution Noncommercial License which permits any noncommercial use, distribution, and reproduction in any medium, provided the original author(s) and source are credited.

\section{References}

Adobe Systems Incorporated. (2002). Photoshop 7.0 for Windows. San Jose: Adobe Systems.

Albernaz, A. L., \& Magnusson, W. (1999). Home-range size of the bare-ear marmoset (Callithrix argentata) at Alter do Chão, Central Amazonia, Brazil. International Journal of Primatology, 20, 665-667.

Anderson, S. (1997). Mammals of Bolivia: taxonomy and distribution. Bulletin of the American Museum of Natural History, 231, 1-652.

Arroyo-Rodríguez, V., Mandujano, S., \& Denítez-Malvido, J. (2008). Landscape attributes affecting patch occupancy by howler monkeys (Alouatta palliata mexicana) at Los Tuxtlas, Mexico. American Journal of Primatology, 70, 69-77.

Baldwin, J. D., \& Baldwin, J. I. (1976). Primate populations in Chiriqui, Panama. In R. W. Thorington Jr. \& P. G. Heltne (Eds.), Neotropical primates: Field studies and conservation (pp. 20-31). Washington: National Academy of Sciences.

Baranga, D. (2004). Red-tail monkey groups in forest patches outside the protected area system in the 'Kampala Area'. African Journal of Ecology, 42(Supplement 1), 78-83.

Bobadilla, U. L., \& Ferrari, S. F. (2000). Habitat use by Chiropotes satanas utahicki and syntopic Platyrrhines in Eastern Amazonia. American Journal of Primatology, 50, 215-224.

Brown, J. H., Mehlman, D. W., \& Stevens, G. C. (1985). Spatial variation in abundance. Ecology, 76, 2028-2043.

Buckland, S. T., Anderson, D. R., Burnham, K. P., \& Laake, J. L. (1993). Distance sampling, estimating abundance of biological populations. London: Chapman \& Hall.

Camacho, M. O., Corsero, W. Q., Martínez, T. I., \& Rojas, D. M. (2001). Tasa de deforestación del Departamento de Santa Cruz, Bolivia 1993-2000. Proyecto de Manejo Forestal Sostenible (BOLFOR), Superintendencia Forestal, Santa Cruz de la Sierra, Bolivia.

Chapman, C. A., \& Peres, C. A. (2001). Primate conservation in the new millennium: the role of scientists. Evolutionary Anthropology, 10, 16-33.

Chapman, C. A., Lawes, M. J., Naughton-Treves, L., \& Gillespie, T. (2003). Primate survival in communityowned forest fragments: Are metapopulation models useful amidst intensive use? In L. K. Marsh (Ed.), Primates in fragments: Ecology and conservation (pp. 63-78). Washington: Kluwer Academic/Plenum.

Chiarello, A. G. (1999). Effects of fragmentation of the Atlantic Forest on mammal communities in southeastern Brazil. Biological Conservation, 89, 71-82.

Chiarello, A. G. (2003). Primates of the Brazilian Atlantic forest: The influence of forest fragmentation on survival. In L. K. Marsh (Ed.), Primates in fragments: Ecology and conservation (pp. 63-78). Washington: Kluwer Academic/Plenum.

Chiarello, A. G., \& De Melo, F. R. (2001). Primate population densities and sizes in Atlantic Forest remnants of Northern Espíritu Santo, Brazil. International Journal of Primatology, 22, 379-396.

Coimbra-Filho, A. F., \& Mittermeier, R. A. (1981). Ecology and behavior of Neotropical primates. Rio de Janeiro: Academia Brasileira de Ciências.

Duarte-Quiroga, A., \& Estrada, A. (2003). Primates as pets in Mexico City: an assessment of the species involved, source of origin, and general aspects of treatment. American Journal of Primatology, 61, 53-60.

Eisenberg, J. F., \& Redford, K. H. (1999). Mammals of the Neotropics. The central Neotropics, Vol. 3: Ecuador, Peru, Bolivia, Brazil. Chicago: University of Chicago Press.

Emmons, L. H., \& Feer, F. (1997). Neotropical rainforest mammals. A field guide (2nd ed.). Chicago: University of Chicago Press.

Emmons, L. H., Whitney, B. M., \& Ross, D. L. Jr. (1997). Sounds of Neotropical rainforest mammals. An audio field guide (CD). Library of Natural Sounds, Cornell Laboratory of Ornithology, Ithaca, New York.

Ferrari, S. F., Iwanaga, S., Ravetta, A. L., Freitas, F. C., Sousa, B. A. R., Souza, L. L., et al. (2003). Dynamics of primate communities along the Santarém-Cuiabá highway in South-Central Brazilian Amazonia. In L. K. Marsh (Ed.), Primates in fragments: Ecology and conservation (pp. 63-78). Washington: Kluwer Academic/Plenum.

Fragaszy, D. M., Visalberghi, E., \& Fedigan, L. M. (2004). Behavioral ecology: How do capuchins make a living? In D. M. Fragaszy, E. Visalberghi, \& L. M. Fedigan (Eds.), The complete capuchin: The biology of the genus Cebus (pp. 36-54). Cambridge: Cambridge University Press. 
Galetti, M., \& Pedroni, F. (1994). Diet of capuchin monkeys (Cebus apella) in a semideciduous forest in South-east Brazil. Journal of Tropical Ecology, 10, 27-39.

Gentry, A. (1993). Dry forest vegetation and phytogeography in the Tucavaca valley. In T. A. Parker III, A. Gentry, R. B. Foster, L. H. Emmons, \& J. V. Remsen Jr. (Eds.), The lowland dry forests of Santa Cruz, Bolivia: A global conservation priority (pp. 40-42). Washington: RAP Working Papers 4.

Gentry, A. (1995). Diversity and floristic composition of Neotropical dry forests. In S. H. Bullock, H. A. Mooney, \& E. Medina (Eds.), Seasonal dry tropical forests (pp. 146-194). Cambridge: Cambridge University Press.

González-Solís, J., Guix, J. C., Mateos, E., \& Llorens, L. (2001). Population density of primates in a large fragment of the Brazilian Atlantic Rainforest. Biodiversity and Conservation, 10, 1267-1282.

Groves, C. P. (2001). Primate taxonomy. Washington: Smithsonian Institution Press.

Guillén Villarroel, R., Rodriguez de Guillén, A., Rocha, N., Herrera, M., Montaño Flores, R. R., Justiniano Chavez, M. M., et al. (2004). Diagnóstico biológico Parque Regional Lomas de Arena. Museo de Historia Natural Noel Kempff Mercado, Fundación Simon I. Patiño, Santa Cruz de la Sierra.

Harcourt, A. H., \& Doherty, D. A. (2005). Species-area relationships of primates in tropical forest fragments: a global analysis. Journal of Applied Ecology, 42, 630-637.

Haselmayer, J., \& Quinn, J. S. (2000). A comparison of point counts and sound recording as bird survey methods in Amazonian Southeast Peru. The Condor, 102, 887-893.

Hershkovitz, P. (1977). Living New World monkeys (Platyrrhini) (Vol. 1). Chicago: University of Chicago Press.

Ibisch, P. L., Beck, S. G., Gerkmann, B., \& Carretero, A. (2003). Ecorregiones y ecosistemas. In P. L. Ibisch \& L. Mérida (Eds.), Biodiversidad: La riqueza de Bolivia (pp. 47-88). Santa Cruz de la Sierra: Editorial FAN.

Janzen, D. H. (1988). Management of habitat fragments in a tropical dry forest: growth. Annals of the Missouri Botanical Garden, 75, 105-116.

Jerusalinsky, L., Oliveira, M. M., Pereira, R. F., Santana, V., Bastos, P. C. R., \& Ferrari, S. F. (2006). Preliminary evaluation of the conservation status of Callicebus coimbrai in the Brazilian State of Sergipe. Primate Conservation, 21, 25-32.

Killeen, T. J., Jardim, A., Mamani, F., \& Saravia, P. (1998). Diversity, composition, and structure of a semideciduous forest in the Chiquitanía region of Santa Cruz, Bolivia. Journal of Tropical Ecology, 14, 803-827.

Kinzey, W. G., Rosenberger, A. L., Heisler, P. S., Prowse, D. L., \& Trilling, J. S. (1977). A preliminary field investigation of the yellow-handed titi monkey, Callicebus torquatus torquatus, in Northern Peru. Primates, 18, 159-181.

Krüger, J.-P. (2006). Forest conversion and soil degradation in the tropical lowland of eastern Bolivia: GIS-based analysis for regionalization of soil degradation in the Santa Cruz Department. Dissertation, 173 pp. plus Appendix. Geographic Institute, Department of Landscape Conservation, University of Göttingen, Germany.

Lande, R., \& Barrowclough, G. F. (1987). Effective population size, genetic variation, and their use in populations management. In M. E. Soulé (Ed.), Viable populations for conservation (pp. 87-123). Cambridge: Cambridge University Press.

Laurance, W. F., \& Bierregaard, R. O. (Eds.). (1997). Tropical forest remnants: Ecology, management, and conservation of fragmented communities. Chicago: University of Chicago Press.

Laurance, W. F., Vasconcelos, H. L., \& Lovejoy, T. E. (2000). Forest loss and fragmentation in the Amazon: implications for wildlife conservation. Oryx, 34, 39-45.

Maas, J. M. (1995). Conversion of tropical dry forest to pasture and agriculture. In S. H. Bullock, H. A. Mooney, \& E. Medina (Eds.), Seasonally dry tropical forests (pp. 399-422). Cambridge: Cambridge University Press.

Martins, M. M. (2005). Density of primates in four semi-deciduous forest fragments of São Paulo, Brazil. Biodiversity and Conservation, 14, 2321-2329.

Mason, W. A. (1971). Field and laboratory studies of social organization in Saimiri and Callicebus. Primate Behavior, 2, 107-137.

Mittermeier, R. A., \& Coimbra-Filho, A. F. (1977). Primate conservation in Brazilian Amazonia. In H. S. H. Prince Rainier \& G. H. Bourne (Eds.), Primate conservation (pp. 117-166). New York: Academic Press.

Mittermeier, R. A., \& van Roosmalen, M. G. M. (1981). Preliminary observations on habitat utilization and diet of eight Surinam monkeys. Folia Primatologica, 36, 1-39.

Mittermeier, R. A., Valladares-Pádua, C., Rylands, A. B., Eudey, A. A., Butynski, T. M., Ganzhorn, J. U., et al. (2005). Primates in peril: The world's 25 most endangered primates 2004-2006. IUCN/SSC Primate Specialist Group (PSG), International Primatological Society (IPS), Conservation International (CI), Washington, DC. 
Murphy, P. G., \& Lugo, A. E. (1995). Dry forests of Central America and the Caribbean. In S. H. Bullock, H. A. Mooney, \& E. Medina (Eds.), Seasonal dry tropical forests (pp. 9-34). Cambridge: Cambridge University Press.

Navarro, G., \& Maldonado, M. (2002). Geografía Ecológica de Bolivia. Vegetación y Ambientes Acuáticos. Fundación Simon I. Patiño, Departamento de Difusión, Cochabamba.

Nowak, R. M. (1999). Walker's primates of the world. Baltimore: The Johns Hopkins University Press.

Peres, C. A. (1997). Effects of habitat quality and hunting pressure on arboreal folivore densities in Neotropical forests: a case study of howler monkeys (Alouatta spp.). Folia Primatologica, 68, 199-222.

Peres, C. A. (1999). General guidelines for standardizing line-transect surveys of tropical forest primates. Neotropical Primates, 7(1), 11-16.

Peres, C. A. (2001). Synergistic effects of subsistence hunting and habitat fragmentation on Amazonian forest vertebrates. Conservation Biology, 15, 1490-1505.

Peres, C. A., \& Dolman, P. M. (2000). Density compensation in Neotropical primate communities: evidence from 56 hunted and nonhunted Amazonian forests of varying productivity. Oecologia, 122, 175-189.

Phillips, O. L., et al. (2004). Pattern and process in Amazon tree turnover, 1976-2001. Philosophical Transactions of the Royal Society of London B, 359, 381-407.

Pinto, N., Lasky, J., Bueno, R., Keitt, T. H., \& Galetti, M. (2009). Primate densities in the Atlantic Forest of Southeast Brazil: The role of habitat quality and anthropogenic disturbance. In P. A. Garber, A. Estrada, J. C. Bicca-Marques, E. W. Heymann, \& K. B. Strier (Eds.), South American primates: Comparative perspectives in the study of behavior, ecology, and conservation (pp. 413-431). New York: Springer.

Robinson, J. G., \& Redford, K. H. (Eds.). (1991). Neotropical wildlife use and conservation. Chicago: Chicago University Press.

Rode, K. D., Chapman, C. A., McDowell, L. R., \& Stickler, C. (2006). Nutritional correlates of population density across habitats and logging intensities in redtail monkeys (Cercopithecus ascanius). Biotropica, 38, 625-634.

Rylands, A. B. (1987). Primate communities in Amazonian forests: their habitats and food resources. Experientia, 43, 267-279.

Salazar-Bravo, J., Tarifa, T., Aguirre, L. F., Yensen, E., \& Yates, T. L. (2003). Revised checklist of Bolivian mammals. Occasional Papers Museum of Texas Tech University, 220, 1-27.

Sánchez-Azofeifa, G. A., Kalacska, M., Quesada, M., Calvo-Alvarado, J. C., Nassar, J. M., \& Rodríguez, J. P. (2005). Need for integrated research for a sustainable future in tropical dry forests. Conservation Biology, 19, 285-286.

Schwarzkopf, L., \& Rylands, A. B. (1989). Primate species richness in relation to habitat structure in Amazonian rainforest fragments. Biological Conservation, 48, 1-12.

Stallings, J. R., \& Mittermeier, R. A. (1989). The black-tailed marmoset (Callithrix argentata melanura) recorded from Paraguay. American Journal of Primatology, 4, 159-163.

Steininger, M. K., Tucker, C. J., Ersts, P., Killeen, T. J., Villegas, Z., \& Hecht, S. B. (2001). Clearance and fragmentation of tropical deciduous forest in the Tierras Bajas, Santa Cruz, Bolivia. Conservation Biology, 15, 856-866.

Sussman, R. W. (2000). Primate ecology and social structure, Vol. 2: New World monkeys. Boston: Pearson Custom Publishing.

Van Roosmalen, M. G. M., Van Roosmalen, T., \& Mittermeier, R. A. (2002). A taxonomic review of titi monkeys, genus Callicebus Thomas, 1903, with the description of two new species, Callicebus bernhardi and Callicebus stephennashi from Amazonia. Neotropical Primates, 10 (Supplement), 1-52.

Veracini, C. (1997). O comportamento alimentar de Callithrix argentata (Linnaeus 1771) (Primata, Callitrichinae). In P. L. B. Caxiuanã (Ed.), Museu Paraense Emilio Goeldi, Belém (pp. 437-446).

Wallace, R. B., Painter, R. L. E., \& Taber, A. B. (1998). Primate diversity, habitat preferences, and population density estimates in Noel Kempff Mercado National Park, Santa Cruz Department, Bolivia. American Journal of Primatology, 46, 197-211.

Williams, M. (1989). Deforestation: past and present. Progress in Human Geography, 13, 176-208. 